\title{
Saline Solution Oral Hygiene dalam Meningkatkan Nafsu Makan Pasien Anoreksia
}

\author{
Dhina Widayati $^{1}{ }^{*}$, Sulistyowati Ariningsih ${ }^{2}$, Muhammad Taukhid $^{3}$ \\ ${ }^{1,2,3}$ Program Studi Sarjana Keperawatan, STIKES Karya Husada Kediri, Kediri 64225, \\ Indonesia \\ *Alamat Korespondensi: Jl. Soekarno Hatta No. 7, Darungan, Kec. Pare, Kediri, Jawa \\ Timur 64225, Telp. (0354) 395203, Faks. 395203 \\ Email: budinawida@gmail.com
}

Diterima: 16 April 2021 |Disetujui: 8 Juni 2021

\begin{abstract}
Abstrak
Latar Belakang dan Tujuan: Anoreksia seringkali menjadi keluhan pada pasien yang dapat menggangu pemenuhan kebutuhan nutrisi akibat penurunan nafsu makan oleh karena rasa tidak nyaman pada mulut. Penelitian ini bertujuan untuk mengetahui pengaruh oral hygiene menggunakan larutan garam terhadap nafsu makan pada pasien anoreksia di RS Amelia Pare.

Metode: Desain penelitian yang digunakan adalah Pre Eksperimen Design dengan pendekatan one group pre-post design. Populasi pada penelitian ini adalah seluruh pasien yang mengalami anoreksia yang sedang rawat inap di RS Amelia. Waktu penelitian 15-29 Februari 2020. Tehnik pengambilan sampel dilakukan dengan accidental samplingdan didapatkan 30 orang responden. Instrumen penelitian dengan kuisioner dan lembar observasi, uji statistik yang digunakan adalah Wilcoxon Signed Rank Test.

Hasil: Hasil penelitian menunjukkan terjadi peningkatan kriteria nafsu makan sebelum dan sesudah intervensi, yakni dari cukup buruk menjadi cukup baik. Berdasarkan uji wilcoxon signed rank test, didapatkan nilai $p$ value $=0,001$ atau nilai $p<\alpha$ yang artinya terdapat pengaruh oral hygiene menggunakan larutan garam terhadap peningkatan nafsu makan pada pasien anoreksia.

Simpulan dan Implikasi: Oral hygiene menggunakan larutan garam dapat meningkatkan nafsu makan pasien anoreksia. Garam mengandung natrium klorida yang secara alami bersifat osmosis yang bekerja menyerap cairan dalam jaringan atau sel dan dapat membuat basa, sehingga meningkatkan $\mathrm{pH}$ dalam mulut yang dapat membatasi jumlah pertumbuhan bakteri sehingga kenyamanan pada rongga mulut meningkat dan nafsu makan menjadi lebih baik. Penelitian ini dapat menjadi intervensi dalam penatalaksanan gangguan pemenuhan kebutuhan nutrisi yang diakibatkan oleh kurangnya nafsu makan pada pasien anoreksia.
\end{abstract}

Kata Kunci: Anoreksia; Larutan Garam; Nafsu Makan; Oral hygiene

Sitasi: Widayati, D., Ariningsih, S., \& Taukhid, M. (2021). Saline solution oral hygiene dalam meningkatkan nafsu makan pasien anoreksia. The Indonesian Journal of Health Science. 13(1), 1-11. DOI: 10.32528/ijhs.v13i1.4902

Copyright: () 2021 Widayati, et al. This is an open-access article distributed under the terms of the Creative Commons Attribution-NonCommercial 4.0 International License, which permits unrestricted use, distribution, and reproduction in any medium, provided the original author and source are credited.

Diterbitkan Oleh: Universitas Muhammadiyah Jember

ISSN (Print): 2087-5053

ISSN (Online): 2476-9614

DOI : 10.32528/ijhs.v13i1.4902 


\begin{abstract}
Background and Aim: Anorexia is often a complaint in patients which can interfere nutritional needs due to decreased appetite becaause of discomfort in the mouth. One of the efforts to increase the patient's appetite can be done by increasing the comfort of the oral cavity through oral hygiene using a saline solution. This research aims to determine the effect of salt solution rinses on appetite in anorexia patients at Amelia Pare Hospital.

Methods: The research design used was Pre Experiment Design with one group pre-post design approach. The population in this research were all patients with anorexia who were hospitalized at Amelia Hospital. Research time was 15-29 February 2020. The sampling technique was done by accidental sampling, as many as 30 respondents. The research instrument was a questionnaire and observation sheet, the statistical test used was the Wilcoxon Signed Rank Test.

Results: The results showed an increase in appetite criteria before and after the intervention, from bad enough to good enough. Based on the Wilcoxon signed rank test, the $p$ value $=0.001$ or $p$ value $<$, which means that there is an effect of oral hygiene using saline solution on increasing appetite in anorexic patient.

Conclusion: Oral hygiene using saline solution can increase the appetite of anorexic patients. Salt contains sodium chloride which is naturally osmotic which works to absorb fluids in tissues or cells and can make alkaline, thereby increasing the $\mathrm{pH}$ in the mouth which can limit the number of bacterial growth so that comfort in the oral cavity increases and appetite becomes better. This study is expected to be one of the interventions in the management of disorders of fulfilling nutritional needs caused by lack of appetite in anorexic patients.
\end{abstract}

Keywords : Anorexic; Appetite; Oral hygiene; Salt solution

\section{PENDAHULUAN}

Makanan mengandung unsur nutrien (zat gizi) yang diperlukan oleh tubuh untuk menghasilkan energi, menggantikan jaringan yang rusak, dan memproduksi substansi tertentu (misalnya: enzim, hormon dan antibodi). Makanan yang diambil tubuh melalui mulut, dicerna dan diserap dalam saluran cerna, akan menjalani proses metabolisme (Nuari, 2015). Metabolisme adalah proses pengolahan zat gizi makanan yang telah diserap oleh tubuh untuk diubah menjadi energi. Energi yang terbentuk selanjutnya digunakan untuk menunjang segala fungsi tubuh, dari bernapas, berpikir, bertumbuh, hingga setiap pergerakan untuk melakukan berbagai aktivitas sehari-hari. Dalam hal ini untuk mendapatkan tubuh yang sehat harus makan yang cukup dan mengandung gizi dan nutrisi, karena makanan dapat membentuk antibodi (daya tahan tubuh) untuk menghalau semua penyakit yang menyerang. Pengaruh makanan (nutrisi) sangat penting untuk semua orang, terlebih pada orang yang sedang sakit. Akan tetapi banyak orang sakit yang mengalami penurunan nafsu makan (anoreksia), terutama pada pasien yang menjalani rawat inap di Rumah Sakit. Anoreksia seringkali disebabkan adanya gangguan pada saluran pencernaan, yang didapatkan dengan keluhan serupa dengan sindrom dyspepsia. Dispepsia sering dipakai sebagai sinonim dari gangguan pencernaan (Guyton, A. C., Hall, 2014). Walapun dispepsia termasuk dalam jenis penyakit yang tidak 
menular namun prevalensi di Indonesia dan dunia cukup tinggi (WHO, 2017). Indonesia menempati urutan ke-3 dengan jumlah penderita terbanyak dispepsia setelah negara Amerika dan Inggris (Depkes RI, 2011). Menurut profil data kesehatan tahun 2011, dispepsia termasuk dalam sepuluh besar penyakit rawat inap. Dari data Rekam Medik RS Amelia, pada bulan Juli sampai September 2019 dispepsia masuk pada urutan ke-3 pada penyakit rawat inap. Berdasarkan survei awal di RS Amelia yang dilakukan pada 10 pasien rawat inap dengan berbagai diagnosis medis didapatkan $60 \%$ pasien yang mengalami penurunan nafsu makan (anoreksia). Mayoritas pasien hanya menghabiskan makanannya 1 sampai 3 sendok makan dan mereka juga tidak berminat untuk makan sesuatu apapun karena merasa tidak nyaman di rongga mulut dan perutnya (Rekam Medis, 2019).

Pada pasien yang mengalami anoreksia didapatkan mayoritas keluhan: mual, muntah, nyeri tenggorokan setelah muntah, tidak enak makan karena mulut terasa pahit dan perut terasa begah. Muntah dapat menimbulkan rasa tidak nyaman, karena dapat menyebabkan iritasi pada selaput lendir di tenggorokan, hal ini akan menimbulkan rasa nyeri sehingga membuat nyeri telan dan radang (faringitis) hingga sulit menelan (disfagia). Ada sebagian terdapat sariawan dalam rongga mulut yang membuat nyeri saat membuka mulut sehingga membuat nafsu makan menurun dan bahkan hilang.

Nafsu makan yang menurun jika dibiarkan dapat mengganggu kondisi kesehatan tubuh dan dapat memperparah keadaan saat sakit (Widayati, D., Yususf, A., Fitriyasari, 2014). Hal ini dapat mengakibatkan menurunya asupan nutrisi untuk pembentukan daya tahan tubuh pasien, sehingga dapat menghambat proses penyembuhan dan juga akan memperpanjang waktu rawat inap.

Supaya tubuh cepat kembali prima dan dapat mempercepat proses penyembuhan penyakit pada pasien anoreksia, diperlukan suatu cara untuk meningkatkan nafsu makan yang menurun. Salah satu cara mengatasi masalah pada anoreksia, yaitu dengan mengkaji penyebab menurun dan hilangnya nafsu makan. Untuk mengatasi masalah ketidaknyamanan pada saluran pencernaan, terutama rasa tidak nyaman pada rongga mulut dapat dilakukan oral hygiene dengan kumur larutan garam. Diantara manfaat kumur larutan garam, yaitu: dapat mengatasi radang tenggorokan, mengatasi bau mulut (halitosis), dan mengatasi sakit pada gigi, sesuai dengan hasil penelitian yang dilakukan oleh (Janna, 2019) yang menunjukkan bahwa berkumur menggunakan air garam dapat menurunkan nyeri pada gigi dan meningkatkan kenyamanan pada rongga mulut.

Hal ini berkaitan dengan tekanan osmosis yang tinggi dari larutan garam. Pada seseorang yang membersihkan mulut dengan cara berkumur menggunakan larutan garam dengan kandungan utama berupa natrium klorida akan terjadi mekanisme osmotik (penyerapan cairan di dalam sel dan jaringan). Secara anatomi, bagian dalam rongga mulut manusia tersusun atas lapisan mukosa yang bersifat lembab sehingga dapat menjadi lingkungan yang ideal bagi pertumbuhan bakteri. Pada seseorang yang membersihkan mulut dengan cara berkumur menggunakan larutan garam, kondisi mulut akan menjadi kering yang terjadi akibat mekanisme osmotik yaitu natrium klorida akan menyerap kelebihan 
cairan dalam mulut.

Kondisi mulut yang kering membuat lingkungan di dalam rongga mulut tidak lagi ideal untuk pertumbuhan bakteri, sehingga bakteri akan berhenti berkembangbiak dan mati. Dengan demikian kondisi rongga mulut yang bersih dan nyaman akan merangsang nafsu makan pasien, sehingga dapat membuat terpenuhinya kebutuhan nutrisi dan mempercepat proses penyembuhan penyakit yang diderita. Tujuan penelitian ini untuk mengetahui pengaruh oral hygiene menggunakan larutan garam terhadap nafsu makan pada pasien anoreksia di RS Amelia.

\section{METODE PENELITIAN}

Desain yang digunakan dalam studi ini adalah pre-experimental dengan pendekatan pre-post test design. Besar sampel sebanyak 30 responden yang diperoleh melalui accidental sampling. Peneliti menetapkan batasan waktu dua minggu untuk mendapatkan sampel yakni 15-29 Februari 2020. Kriteria inklusi dalam penelitian ini: (a) Pasien rawat inap yang mengalami anoreksia dengan keluhan: tidak nyaman pada rongga mulut (seperti sariawan, radang tenggorokan, rasa asam dan rasa pahit di lidah) dan (b) Kesadaran composmentis. Sedangkan kriteria eksklusi: (a) Mengalami muntah, (b) Mengalami gangguan kesadaran pada saat penelitian, (c) Mengundurkan diri saat penelitian, (d) Pulang sebelum mencapai 2 kali intervensi, (e) Hipertensi, (f) Stroke yang mengalami kelemahan pada saraf facialis.

Variabel independen pemberian kumur larutan garam dan variabel dependen nafsu makan. Kumur larutan garam diberikan $2 x /$ hari (pagi dan sore 5 menit sebelum makan) dengan 3 gr garam meja yang dilarutkan dengan $240 \mathrm{ml}$ air. Berkumur larutan larutan garam dengan durasi 30 detik tiap kumur, sampai $240 \mathrm{ml}$ larutan larutan garam habis. Data nafsu makan diperoleh melalui lembar observasi dan wawancara. Penilaian nafsu makan didasarkan pada dua parameter yakni: (1) Keinginan makan/minat makan (responden diminta menunjukkan nilai keinginan makan saat ini) dan (2) Asupan makanan (jumlah porsi makanan yang dikonsumsi responden).

Instrumen untuk menilai minat makan responden menggunakan wawancara tertutup dengan cara menanyakan keinginan makan responden dalam rentang 1-5, yakni skor 1 jika responden tidak minat makan, Skor 2 jika responden kurang minat makan, skor 3 jika responden cukup minat makan, skor 4 jika responden minat makan, skor 5 jika responden sangat minat makan.

Sedangkan untuk mengetahui jumlah asupan makan responden dilakukan melalui observasi pada banyaknya porsi makanan yang dihabiskan. Lembar observasi memuat option jumlah porsi responden yang terbagi dalam kriteria: skor 1 jika diit/makanan yang dihabiskan <1/5 porsi, skor 2 jika diit/makanan yang dihabiskan $1 / 5-<2 / 5$ porsi, skor 3 jika diit/makanan yang dihabiskan 2/5$<3 / 5$ porsi, skor 4 jika diit/makanan yang dihabiskan $3 / 5-<4 / 5$ porsi dan skor 5 jika diit/makanan yang dihabiskan $\geq 4 / 5$ porsi. Selanjutnya dilakukan interpretasi penialian nafsu makan dengan kriteria: buruk (1\%$20 \%)$, cukup buruk (21\%-40\%), sedang (41\%-60\%), cukup baik $(61 \%-80 \%)$ dan baik (81\% - 100\%). 
Analisis data dilakukan menggunakan uji Wilcoxon Signed Rank Test dengan $\alpha=0,05$. Penelitian ini telah dinyatakan laik etik dengan nomor surat: 067/EC/LPPM/STIKES/KH/I/2020.

\section{HASIL PENELITIAN}

Berdasarkan pada Tabel.1 diketahui bahwa pada data umum didapatkan gambaran mayoritas umur responden $(66,7 \%)$ berusia $22-50$ tahun, sebanyak 20 orang; mayoritas jenis kelamin responden $(53,3 \%)$ adalah laki-laki sebanyak 16 orang; rata-rata pendidikan responden adalah SD $(33,3 \%)$ sebanyak 10 orang dan SLTA $(33,3 \%)$ sebanyak 10 orang; mayoritas pekerjaan responden $(56,7 \%)$ adalah wiraswasta sebanyak 17 orang; dan pada diagnosis medis didapatkan mayoritas responden $(56,7 \%)$ sebanyak 17 orang dengan diagnosis medis lainnya (selain DM dan TBC yaitu: ISPA, DF, COPD, tipoid, faringitis, ISK, dispepsia, bronkitis.

Tabel.1 Distribusi frekuensi responden berdasarkan usia, jenis kelamin, pendidikan, pekerjaan dan diagnosis medis

\begin{tabular}{cll}
\hline Karakteristik Responden & Frekuensi & Persen (\%) \\
\hline Usia (th) & 3 & 10.0 \\
$-\quad 14-21$ & 20 & 66.7 \\
$-\quad 22-50$ & 7 & 23.3 \\
- >50 & & \\
Jenis Kelamin & 16 & 53.3 \\
- Laki-laki & 14 & 46.7 \\
- Perempuan & & \\
Pendidikan & 10 & 33.3 \\
- SD & 8 & 26.7 \\
- SLTP & 10 & 33.3 \\
- SLTA & 2 & 6.7 \\
- SARJANA & & \\
Pekerjaan & 9 & 30.0 \\
- Swasta & 17 & 56.7 \\
- Wiraswasta & 4 & 56.4 \\
- Lainnya & & 13.3 \\
Diagnosis Medis & 4 & 30.0 \\
- DM & 9 & .7 \\
- TBC & 17 & \\
- Lainnya & &
\end{tabular}

Tabel. 2 Nafsu makan sebelum diberikan kumur larutan garam pada pasien anoreksia

\begin{tabular}{lcc}
\hline \multicolumn{1}{c}{ Nafsu Makan } & Frekuensi & Persen $(\boldsymbol{\%})$ \\
\hline Buruk & 4 & 13.3 \\
Cukup buruk & 16 & 53.3 \\
Sedang & 8 & 26.7 \\
Cukup baik & 2 & 6.7 \\
\hline Total & $\mathbf{3 0}$ & $\mathbf{1 0 0}$ \\
\hline
\end{tabular}


Tabel. 3 Nafsu makan setelah pemberian kumur larutan garam pada pasien anoreksia

\begin{tabular}{lcc}
\hline \multicolumn{1}{c}{ Nafsu Makan } & Frekuensi & Persen (\%) \\
\hline Buruk & 1 & 3.3 \\
Cukup buruk & 1 & 3.3 \\
Sedang & 6 & 20.0 \\
Cukup baik & 14 & 46.7 \\
Baik & 8 & 26.7 \\
\hline Total & $\mathbf{3 0}$ & $\mathbf{1 0 0}$ \\
\hline
\end{tabular}

Tabel .4 Nafsu makan sebelum diberikan kumur larutan garam dan setelah diberikan kumur larutan garam pada pasien anoreksia

\begin{tabular}{|c|c|c|c|c|c|c|c|c|c|c|c|c|}
\hline \multirow{3}{*}{$\begin{array}{l}\text { Nafsu Makan } \\
\text { pada Pasien } \\
\text { anoreksia } \\
\text { sebelum } \\
\text { diberikan } \\
\text { intervensi }\end{array}$} & \multicolumn{12}{|c|}{$\begin{array}{c}\text { Nafsu Makan Pada pasien anoreksia } \\
\text { setelah diberikan kumur larutan garam }\end{array}$} \\
\hline & \multicolumn{2}{|c|}{ Buruk } & \multicolumn{2}{|c|}{$\begin{array}{l}\text { Cukup } \\
\text { Buruk }\end{array}$} & \multicolumn{2}{|c|}{ Sedang } & \multicolumn{2}{|c|}{$\begin{array}{l}\text { Cukup } \\
\text { Baik }\end{array}$} & \multicolumn{2}{|c|}{ Baik } & \multicolumn{2}{|c|}{ Total } \\
\hline & $\mathrm{N}$ & $\%$ & $\mathrm{~N}$ & $\%$ & $\mathrm{~N}$ & $\%$ & $\mathrm{~N}$ & $\%$ & $\mathrm{~N}$ & $\%$ & $\mathrm{~N}$ & $\%$ \\
\hline Buruk & 1 & 3,3 & 1 & 3,3 & 2 & 6,7 & 0 & 0 & 0 & 0 & 4 & 13,3 \\
\hline Cukup Buruk & 0 & 0 & 0 & 0 & 4 & 13,3 & 8 & 26,7 & 4 & 13,3 & 16 & 53,3 \\
\hline Sedang & 0 & 0 & 0 & 0 & 0 & 0 & 5 & 16,7 & 3 & 10 & 8 & 26,7 \\
\hline Cukup Baik & 0 & 0 & 0 & 0 & 0 & 0 & 1 & 3,3 & 1 & 3,3 & 2 & 6,7 \\
\hline Total & 1 & 3,3 & 1 & 3,3 & 6 & 20 & $\begin{array}{l}1 \\
4\end{array}$ & 46,7 & 8 & 26,7 & 30 & 100 \\
\hline
\end{tabular}

$\mathrm{N}=30, \quad P$-Value $=0,001<0,05, \quad$ Mean $=$ Pre $(39,67)$, post $(74,00)$

Berdasarkan hasil pada Tabel.4 diketahui bahwa mayoritas atau lebih dari setengahnya $(53,3 \%)$ sebelum diberikan kumur larutan garam, nafsu makan pada pasien anoreksia berada pada kriteria cukup buruk. Akan tetapi nafsu makan pada pasien anoreksia setelah diberikan kumur larutan garam mayoritas atau hampir setengahnya $(46,7 \%)$ berada pada kriteria cukup baik.

\section{PEMBAHASAN}

Tingkat nafsu makan sebelum pemberian intervensi menunjukkan lebih dari setengahnya $(53,3 \%)$ pasien anoreksia di RS Amelia Pare berada pada kriteria nafsu makan yang cukup buruk.

Studi literatur menunjukkan bahwa nafsu makan merupakan keadaan yang membuat seseorang DOI : $10.32528 /$ ijhs.v13i1.4902 ingin makan karena adanya selera makan (Patricia, 2010). Selera makan merupakan suatu hal yang komplek dan dipengaruhi oleh banyak faktor, antara lain: sistem saraf, endokrin, psikososial dan faktor lainnya (Guyton, A. C., Hall, 2014). Pada pasien yang menjalani rawat inap, seringkali ditemukan gangguan pemenuhan kebutuhan nutrisi yang diakibatkan oleh anoreksia (Azizah, A., Widayati, D., Rachmania, 2017) . Anoreksia adalah menurunnya keinginan, sensansi atau rangsangan untuk makan (Davidson, G.C., Neale, J.M., 2010). Gangguan nafsu makan ini akan menjadi sesuatu yang sulit diatasi manakala diagnosis penyebabnya tidak diketahui dengan pasti dan dukungan keluarga yang kurang optimal (Wulandari, O., Widayati, 2020). Beberapa faktor 
dapat menyebabkan kondisi gangguan nafsu makan, salah satunya karena tidak adanya selera makan yang diakibatkan oleh kondisi mulut yang kurang nyaman atau dapat juga disebabkan oleh penyakit tertentu (Arief, 2010). Apabila hal ini tidak diatasi dengan baik, maka berkurangnya nafsu makan dapat berakibat pada penurunan berat badan yang menjadi salah satu indikator kecukupan pemenuhan gizi dan nutrisi (Octaviana, 2018). Menurut peneliti berdasarkan identifikasi hasil penelitian pada responden dengan kriteria nafsu makan cukup buruk didapatkan mayoritas pada jenis kelamin perempuan dan sebagian besar pasien mempunyai diagnosis yang beragam, tidak hanya kasus yang berhubungan dengan pencernaan, antara lain: bronkitis, faringitis, Dengue Fever (DF), COPD, dan ISK.

Terjadinya nafsu makan cukup buruk pada jenis kelamin perempuan dibandingkan pada lakilaki didukung oleh (Rokhmah, UF., Purnamasar, DU., 2017) yang menyatakan bahwa wanita cenderung mengalami anoreksia dibanding lakilaki. Anoreksia pada wanita dimungkinkan terjadi karena wanita memiliki kebutuhan energi yang lebih rendah dibandingkan laki-laki, sehingga wanita cenderung mengkonsumsi makanan lebih sedikit. Selain itu faktor hormonal juga turut berperan dalam fluktuasi asupan energi pada wanita.

Berdasarkan diagnosis medis lainnya didapatkan bermacam-macam penyakit. Pada rongga mulut terdapat mikroorganisme (bakteri, virus, dan jamur) yang bisa bersifat patogen. Di mana invasi dari mikoorganisme yang menyebabkan peradangan akan membentuk mediator radang yang akan mempengaruhi nafsu makan secara negatif, sehingga membuat orang sakit makan lebih sedikit. Dalam hal ini dapat disimpulkan bahwa apapun itu penyakit akut ataupun kronis yang disebabkan oleh virus, bakteri, parasit/jamur dapat menyebabkan ketidaknyamanan pada rongga mulut dan menyebabkan seseorang mengalami anoreksia (penurunan nafsu makan).

Anoreksia pada pasien rawat inap dapat disebabkan secara langsung oleh proses penyakit yang meningkatkan aktifitas pusat kenyang dan menghambat atau menekan pusat lapar sehingga seseorang akan merasa kenyang dan tidak ada sensasi ingin makan. Dalam penentuan intervensi untuk mengatasi masalah anoreksia, perlu pengkajian dan analisis mendalam mengenai penyebabnya yang berkaitan dengan sifat dari anoreksia, yaitu patologik, fisiologik, ataukah psikologik. Pada jenis anoreksia sejati, penurunan selera makan terjadi karena penyebab yang jelas (berkaitan dengan gangguann fisiologis pada sistem pencernaan), sedangkan pada anoreksia jenis pseudoanoreksia, penurunan selera makan disebabkan oleh faktor lain (berkaitan dengan gangguan yang memengaruhi kondisi psikologis. Penurunan selera makan dapat bersifat sementara dapat juga karena perubahan rasa menu makanan atau karena penyebab yang lain.

Berdasarkan studi literatur menurut (Pangesti AD, Nym Ari Susanti D, 2018) salah satu manfaat larutan garam dapat dipakai sebagai obat kumur. Referensi dari buku "The Way of Ayuverdic Herbs" menyatakan bahwa masyarakat Tiongkok dan Indian Kuno juga telah menggunakan larutan garam untuk 
membersihkan mulut. Kandungan natrium klorida $(\mathrm{NaCl})$ yang terdapat pada larutan garam dapat menyerap cairan dari sel maupun jaringan di area rongga mulut karena sifatnya yang osmosis. Hal ini sejalan dengan kondisi rongga mulut yang secara anatomi tersusun oleh lapisan mukosa yang bersifat lembap yang menjadi lingkungan ideal dalam pertumbuhan bakteri, sehingga untuk mengurangi kelembapan di dalam rongga mulut dapat dilakukan pembersihan mulut melalui kumur air garam agar konsisi rongga mulut menjadi kering dan tidak cocok bagi pertumbuhan bakteri.

Identifikasi hasil penelitian setelah pemberian kumur larutan garam didapatkan responden pasien anoreksia dengan kriteria nafsu makan cukup baik terdapat pada sebagian besar pasien mempunyai diagnosis yang beragam, tidak hanya kasus yang berhubungan dengan pencernaan, antara lain: bronkitis, faringitis, Dengue Fever (DF), COPD, dan ISK. Dalam hal ini penyakit apapun dapat menyebabkan ketidaknyamanan pada ronggga mulut dan menyebabkan seseorang mengalami anoreksia (penurunan nafsu makan). Di mana gangguan rasa nyaman pada rongga mulut dapat disebabkan oleh adanya rasa asam dan pahit pada lidah dan tenggorokan, hal ini dapat diatasi dengan oral hygiene. Sesuai dengan Standart Intervensi Keperawatan Indonesia (SIKI) untuk mengelola nutrisi yang seimbang karena adanya ketidaknyamanan pada rongga mulut, dapat dilakukan oral hygiene sebelum makan (PPNI, 2018). Salah satu cara oral hygiene dapat dilakukan dengan menggunakan larutan garam. Ketika berkumur dengan larutan garam, natrium klorida akan menyerap kelebihan cairan dalam mulut sehingga membuatnya kering. Di mana lingkungan dalam mulut yang kering tidak lagi ideal untuk bakteri bertahan hidup dan bakteri akan berhenti berkembang biak dan akhirnya mati sehingga rongga mulut yang bersih dan nyaman akan merangsang nafsu makan.

Berdasarkan uji Wilcoxon Signed Rank Test didapatkan nilai $p$ value $=0,001(p<\alpha$, dengan nilai $\alpha=0,05$ ) yang menunjukkan ada pengaruh kumur larutan garam terhadap nafsu makan pada pasien anoreksia di RS Amelia Pare. Adapun diskripsi pengaruh tersebut sebesar Mean 39,67-74,00. Dari hasil penelitian menunjukkan bahwa ada peningkatan nafsu makan pada pasien anoreksia. Di mana pada hasil identifikasi nafsu makan pada pasien anoreksia sebelum diberikan kumur larutan garam mayoritas atau lebih dari setengah responden $(53,3 \%)$ berada pada kriteria cukup buruk. Sedangkan hasil identifikasi nafsu makan pada pasien anoreksia setelah diberikan kumur larutan garam menunjukkan mayoritas atau setengah responden $(46,7 \%)$ berada pada kriteria cukup baik.

Studi literatur menyatakan bahwa mekanisme yang dapat menimbulkan sensasi atau keinginan makan merupakan mekanisme komplek yang melibatkan koordinasi beberapa sistem organ, yaitu saluran cerna, hormon, susunan saraf baik saraf pusat maupun saraf otonom. Secara anatomi dan fisiologi, otak menjadi hal yang sangat penting dalam proses tersebut karena pada otak terdapat hipotalamus sebagai pusat pengatur nafsu makan (LeMone, P. Burke, M.K. Bauldff, 2015). Pada bagian tersebut terdapat 
$\begin{array}{ccr}\text { neuron } & \text { serotoninergik } & \text { yang } \\ \text { bertanggung } & \text { jawab } & \text { dalam }\end{array}$ pengelolaan nafsu makan. Selain itu pengelolaan nafsu makan juga dikontrol oleh neuropeptidea $Y$ (NPY) dan Agouti-relate peptide $(A G R P)$. Sensasi rasa lapar juga terjadi akibat aktivitas dari cabangcabang hypothalamocortical dan hypothalamolimbic

(Guyton, A. C., Hall, 2014).

Pada fisiologi sistem pencernaan, makanan masuk ke tubuh dimulai dari mulut sampai dengan anus. Adanya ketidaknyamanan pada rongga mulut dapat mempengaruhi tipe dan jumlah makanan yang dicerna (Nuari, 2015) . Organ Mulut merupakan bagian awal dari saluran pencernaan yang juga berperan dalam sistem pernafasan (Muttaqin, A. Sari, 2015). Berkaitan dengan jalur awal yang dilalui oleh makanan adalah di mulut, maka mulut dapat dinyatakan sebagai gerbang masuk dan berkembangnnya suatu penyakit (Arief, 2010). Secara fisiologis, di dalam rongga mulut terdapat flora normal yang membantu proses pencernaan makanan, namun pada kondisi tertentu dapat bersifat patogen dan menyebabkan gangguan. Secara alami, rongga mulut akan dibantu pembersihannya oleh produksi saliva dan lidah namun apabila terdapat gangguan maka fungsi pembersihan tersebut kurang optimal sehingga dapat terjadi infeksi pada area tersebut (Nuari, 2015).

Microflora yang dapat berupa bakteri, virus maupun jamur dapat menempati dan berkembang biak di dalam rongga mulut. Microflora jenis bakteri dan jamur yang sering ditemukan adalah streptococcus, salmonella, dan candida albicans. Keberadaan microflora tersebut di dalam rongga mulut apabila tidak dilakukan upaya pembersihan melalui perawatan rongga mulut atau biasa dikenal dengan oral hygiene dapat menyebabkan infeksi (Sriyono, 2011).

Kebersihan mulut berkorelasi signifikan terhadap kenyamanan dan kualitas hidup pasien (Widayati, D., Yususf, A., Fitriyasari, 2014). Pasien rawat inap tentunya membutuhkan perawatan mulut yang baik dalam menunjang pemenuhan kebutuhan nutrisi, komunikasi dan keselamatan pasien. Dalam pemenuhan kebutuhan tersebut, perlu peran penting dari perawat untuk dapat memberikan pelayanan keperawatan secara profesional agar tercipta kepuasan pada pasien (Widayati, 2020b). Salah satu intervensi tersebut dapat diberikan melalui tindakan oral hygiene atau perawatan mulut. Oral higiene merupakan tindakan perawatan untuk membersihkan area keseluruhan rongga mulut, mulai dari mulut, gigi, gusi dan lidah. Melalui tindakan ini diharapkan kenyamanan meningkat dan dapat meningkatkan nafsu makan (Izzati, 2013).

Menurut peneliti, ketidaknyamanan pada rongga mulut dapat mempengaruhi nafsu makan yang menyebabkan anoreksia. Dalam hal ini jika dibiarkan dapat membuat seseorang beresiko untuk mengalami asupan nutrisi yang tidak cukup untuk memenuhi metabolisme. Berdasarkan Standart Intervensi Keperawatan Indonesia (SIKI) untuk mengelola nutrisi yang seimbang karena adanya ketidaknyamanan pada rongga mulut, dapat dilakukan oral hygiene sebelum makan (PPNI, 2018). Oral hygiene dapat dilakukan dengan kumur larutan garam, karena garam mengandung natrium klorida yang dapat membatasi jumlah pertumbuhan bakteri dan garam juga 
mengandung molekul air. Larutan garam dapat dipakai sebagai obat kumur. Penggunaan larutan garam sebagai bahan pembersih mulut juga telah digunakan oleh masyarakat Tiongkok dan Indian Kuno. Kandungan natrium klorida yang terdapat pada larutan garam dapat menarik cairan pada sel dan jaringan karena sifat osmosisnya. Pada rongga mulut manusia tersusun oleh lapisan mukosa dengan tingkat kelembaban yang tinggi yang memungkinkan sebagi tempat yang baik dalam pertumbuhan bakteri dan mikroorganisme lain.

Air asin bermanfaat karena garam dapat membuat basa dan meningkatkan $\mathrm{PH}$ dalam mulut yang mengurangi perkembangan bakteri, karena hampir seluruh bakteri lebih memilih lingkungan asam untuk hidup. Selain basa, larutan garam juga bersifat isotonik dan tidak mengiritasi selaput lendir (Grober, 2012).

Pada penelitian ini didapatkan hasil peningkatan nafsu makan paling signifikan pada responden dengan diagnosis lainnya, yaitu dengan diagnosis medis faringitis, didapatkan rasa tidak nyaman pada rongga mulut dan nyeri tenggorokan, di mana nafsu makan berada pada kriteria cukup buruk dan setelah diberikan kumur larutan garam 5 menit sebelum makan 2x/hari (pagi dan sore) selama 2 hari, nafsu makan meningkat menjadi kriteria cukup baik. Dengan demikian kumur larutan garam mampu memberikan rasa nyaman pada rongga mulut, sehingga dapat mempengaruhi nafsu makan pada pasien anoreksia yang disebabkan oleh karena ketidaknyamanan pada rongga mulut seperti sariawan, radang tenggorokan, rasa asam dan pahit pada lidah. Oleh karena itu, perawat dalam menjalankan salah satu fungsinya yakni sebagai edukator, maka perlu memberikan edukasi pentingnya kegiatan perawatan mulut dalam menunjang pemenuhan kebutuhan nutrisi pasien (Widayati, 2020).

\section{SIMPULAN}

Oral hygiene menggunakan
larutan larutan garam dapat
meningkatkan nafsu makan pada
pasien anoreksia di RS Amelia.
Pemberian oral menggunakan bahan larutan garam dapat dijadikan salah satu intervensi dalam upaya meningkatkan nafsu makan pada pasien dengan anoreksia unutk membantu pemenuhan kebutuhan nutrisi.

\section{DAFTAR PUSTAKA}

Arief, M. (2010). Pengkajian keperawatan pada praktik klinik (12th ed.). Jakarta: EGC.

Azizah, A., Widayati, D., Rachmania, D. (2017). Dischrage planning mempengaruhi kualitas pelayanan keperawatan. Journal of Ners Community, 8(1), 53-63.

Davidson, G.C., Neale, J.M., K. (2010). (2010). Psikologi abnormal (9th ed.). Jakarta: Rajawali Pers.

DEPKES RI. (2011). Pedoman teknis penemuan dan tatalaksana penyakit tidak menular. Jakarta: Direktorat Pengendalian Penyakit Tidak Menular.

Grober, U. (2012). Mikronutrien : penyelaras metabolik, pencegahan, dan terapi (Juli Ita Panggabean, ed.). Jakarta: EGC.

Guyton, A. C., Hall, J. E. (2014). Buku ajar fisiologi kedokteran. (12th ed.). Jakarta: EGC.

Izzati, N. (2013). Pengaruh paemberian 
minyak atsiri temulawak (Curcuma Xanthorrhiza Roxb) terhadap nafsu makan tikus. Repository Universitas Gadjah Mada. Retrieved from hhtp://etd.repository.ugm.ac.id

LeMone, P. Burke, M.K. Bauldff, G. (2015). Buku ajar keperawatan medikal bedah (5th ed.; T. Iskandar, ed.). EGC.

Muttaqin, A. Sari, K. (2015). Gangguan gastrointestinal aplikasi asuhan keperawatan medikal bedah. Jakarta: Salemba Medika.

Nuari, A. . (2015). Buku ajar asuhan keperawatan pada gangguan sistem gastrintestinal. Jakarta: CV Trans info Media.

Octaviana, L. A. K. (2018). Faktorfaktor yang berhubungan dengan upaya keluarga dalam pencegahan penyakit dispepsia di Wilayah Kerja Puskesmas Mangkatup Kabupaten Barito Selatan. Jurnal Langsat, 5(2).

Pangesti AD, Nym Ari Susanti D, K. S. (2018). Perbedaan efektivitas obat kumur yang mengandung chlorhexidine dan essential oils terhadap penurunan tingkat halitosis. Bali Dent J, 2(1), 49-53.

Patricia, A. (2010). Fundametal of nursing edition (7th ed.). Jakarta: Salemba Medika.

PPNI. (2018). Standar intervensi keperawatan indonesia: Definisi dan tindakan keperawatan (1st ed.). Jakarta: DPP PPNI.

Rekam Medis. (2019). Data jumlah pasien rawat inap dispepsia. Kediri.

Rokhmah, UF., Purnamasar, DU., S. (2017). Factors associated with diminished appetite in chronic kidney disease patients undergoing hemodialysis therapy. Jurnal Gipas, 1(1), 23-35.
Sriyono, N. W. (2011). Pengantar ilmu kedokteran gigi. Yogyakarta: FK UGM.

WHO. (2017). Penyakit tidak menular.

Widayati, D., Yususf, A., Fitriyasari, R. P. . (2014). Peningkatan penerimaan pada nyeri kronis, comfort dan kualitas hidup lansia melalui acceptance and commitment therapy. Jurnal Ners, 9(2), 252-261.

Widayati, D. (2020a). Edukasi managemen diabetes berbasis kelompok sebaya sebagai upaya meningkatkan kepatuhan diet dan perawatan mandiri penderita diabetes. The Indonesian Journal of Health Science, 12(2), 137146.

Widayati, D. (2020b). Quality nursing work life dan burnout syndrome pada perawat. Jurnal Ners Dan Kebidanan, 7(1), 123-129.

Wulandari, O., Widayati, D. (2020). Pemberdayaan keluarga dalam menurunkan tingkat kecemasan pasien GGK dengan hemodialisa. Jurnal Care: Jurnal Ilmiah Ilmu Kesehatan, 8(3). 